Vol. 8, Issue 12, December 2021

DOI: $10.17148 / I A R J S E T .2021 .81239$

\title{
MANAGEMENT of BATTERIES WASTE DISPOSAL
}

\author{
Mridula Verma \\ Associate Professor, Department of Chemistry, M.M.H College, Ghaziabad, India
}

\begin{abstract}
Batteries are widely used in daily life, and a large number of batteries waste will eventually be produced. Batteries waste will cause serious environmental pollution. These batteries contain several heavy metals such as cadmium, copper, lead, mercury, nickel or zinc, which are all hazardous to human health and environment. The casual dumping of spent batteries into landfills eventually result in percolation of heavy metals and other toxic compounds into soil and water, contaminating food and water supplies and making them unhealthy for use by mankind and wildlife. The erroneous incineration results in release of certain toxic metals into air through stack gases or accumulation in the ash produced by the combustion process. At present, the main treatment methods of batteries waste are incineration and landfill, solidification treatment, manual sorting, wet recovery technology, dry recovery technology and bio-metallurgical technology. The Batteries (Management and Handling) Rules, 2001 as amended vide SO 1002(E) dt-4-5-2010 have to be followed for the safe disposal of batteries waste.
\end{abstract}

Keywords: Batteries waste, recycle, waste management, Incineration, Land fill

\section{INTRODUCTION}

The Batteries (Management and Handling) Rules, 2001 as amended vide SO 1002(E) dt-4-5-2010 shall apply to every manufacturer, importer, re-conditioner, assembler, dealer, recycler, auctioneer, consumer, and bulk consumer involved in manufacture, processing, sale, purchase and use of batteries or components thereof. A battery is a device to transform the chemical energy contained in its active materials, directly into electrical energy by means of an electrochemical oxidation-reduction (redox) reaction . Batteries have a unique mechanism as there are no moving parts but they still manage to carry electric current through circuits. There are many kinds of batteries, which can be roughly divided into primary batteries, secondary batteries and fuel cells. Primary batteries refer to batteries that cannot be recharged after discharge. They can also be called dry batteries, such as ordinary zinc-manganese batteries and alkaline zinc manganese batteries. Secondary batteries refer to batteries that can be recharged and recovered after discharge and can be used many times. They can also be called storage batteries and rechargeable batteries, such as lithium batteries and lead-acid batteries. Fuel cell is a device that directly converts chemical energy in fuel into electric energy, and it can also be called electrochemical generator. A chemical or physical condition that has the potential to cause damage to people, property, or the environment is termed as a Hazard. A battery that is no longer wanted or is unusable for its intended purpose and is intended for storage, recycling or disposal is termed as a waste battery . Most of the batteries contain toxic heavy metals such as mercury, cadmium, lead, nickel, zinc, or copper, which are all hazardous to human health and environment. However, the Basel Convention considers only the batteries containing cadmium, lead and mercury as hazardous. While the batteries that do not contain cadmium, lead or mercury such as alkaline manganese and zinc carbon are classified as non-hazardous. When waste batteries are thrown away in the trash, they end up in landfills. The toxic heavy metals/compounds in these batteries can contaminate the environment by leaching into soil and water, polluting water bodies and making them unfit for use by mankind and wildlife. When incinerated, certain toxic metals might release into air through stack gases or can accumulate in the ash produced by the combustion process $[1,2,3,4,5,6]$.

\section{PROCEDURE for REGISTRATION/RENEWAL of RECYCLERS}

(a) Every recycler of used lead acid batteries shall make an application in Form VI along with the following documents to the Joint Secretary, Ministry of Environment and Forests or any officer designated by the Ministry or an agency designated by it for grant of registration or renewal [1].

(1) a copy of the valid consents under Water (Prevention and Control of Pollution) Act, 1974, as amended and Air (Prevention and Control of Pollution) Act, 1981, as amended.

(2) a copy of the valid authorization under Hazardous Wastes (Management and Handling) Rules, 1989 as amended.

(3) a copy of valid certificate of registration with District Industries Centre.

(4) a copy of the proof of installed capacity issued by either State Pollution Control Board/District Industries Centre. 
DOI: $10.17148 /$ IARJSET.2021.81239

(b) The Joint Secretary, Ministry of Environment and Forests or any officer designated by the Ministry or an agency designated by it shall ensure that the recyclers possess appropriate facilities, technical capabilities, and equipment to recycle used batteries and dispose of hazardous waste generated [1].

(c) The Joint Secretary, Ministry of Environment and Forests or any officer designated by the Ministry or an agency designated by it shall take decision on application for registration within 90 days of receipt of application form with complete details[2].

(d) The registration granted under this rule shall be in force for a period of two years from the date of issue or from the date of renewal unless suspended or cancelled earlier;

(e) An application for the renewal of registration shall be made in Form VI at least six months before its expiry. The Joint Secretary, Ministry of Environment and Forests or any officer designated by the Ministry or an agency designated by it shall renew the registration of the recycler granted under sub rule(4) of this rule, after examining each case on merit [1].

(f) The Joint Secretary, Ministry of Environment and Forests or any officer designated by the Ministry or an agency designated by it may, after giving reasonable opportunity to the applicant of being heard, refuse to grant registration;

(g) The Joint Secretary, Ministry of Environment and Forests or any officer designated by the Ministry or an agency designated by it may cancel or suspend a registration issued under these rules, if in his/her opinion, the registered recycler has failed to comply with any of the conditions of registration, or with any provisions of the Act or rules made there under after giving him an opportunity to explain and after recording the reasons there for;

(h) It shall be the responsibility of the State Boards to monitor the compliance of conditions prescribed while according registration.

(i) An appeal shall lie against any order of suspension or cancellation or refusal of registration passed by the Joint Secretary to the Ministry of Environment and Forests or any officer designated by the Ministry or agency designated by it. The appeal shall be in writing and shall be accompanied with a copy of the order appealed against and shall be presented within 30 days of passing of the order.

\section{REGISTRATION OF IMPORTERS}

(a) The importers shall get registered as per Form I with the Central Pollution Control Board for a period of five years and a provision of cancellation for failure in collection of the required number of used batteries as per the said rules, non-submission of timely half yearly returns to the State Pollution Control Boards with a copy to the Central Pollution Control Board, renewal of the registration shall be as per the compliance status. Provided that the registration granted to the importer shall not be cancelled unless he has been given a reasonable opportunity of hearing [2].

(b) An appeal shall lie against any order of suspension or cancellation or refusal of registration passed by the MemberSecretary of the Central Pollution Control Board or any other officer designated by the Central Pollution Control Board [2].

(c) The appeal shall be in writing and shall be accompanied with a copy of the order appealed against and shall be made within period of thirty days from the date of passing of the order [2].

\section{RESPONSIBILITIES}

\section{A. RESPONSIBILITIES of MANUFACTURER, IMPORTER, ASSEMBLER and RE-CONDITIONER}

It shall be the responsibility of a manufacturer, importer, assembler and re-conditioner to

(a) Ensure that the used batteries are collected back as per the Schedule against new batteries sold excluding those sold to original equipment manufacturer and bulk consumers [1].

(b) Ensure that used batteries collected back are of similar type and specifications as that of the new batteries sold.

(c) File a half-yearly return of their sales and buy-back to the State Board in Form- I latest by 30th June and 31st December of every year [1].

(d) Set up collection centres either individually or jointly at various places for collection of used batteries from consumers or dealers.

(e) Ensure that used batteries collected are sent only to the registered recyclers.

(f) Ensure that necessary arrangements are made with dealers for safe transportation from collection centres to the premises of registered recyclers [1].

(g) Ensure that no damage to the environment occurs during transportation.

(h) Create public awareness through advertisements, publications, posters or by other means with regard to the following:

(1) hazards of lead;

(2) responsibility of consumers to return their used batteries only to the dealers or deliver at designated collection centres; 
(3) addresses of dealers and designated collection centres.

(i) Use the international recycling sign on the Batteries.

(j) Buy recycled lead only from registered recyclers.

(k) Bring to the notice of the State Board or the Ministry of Environment and Forests any violation by the dealers.

(1) Ensure that the new batteries shall be sold only to the registered dealers [2].

Note: The assemblers and reconditioners are excluded from the purview of responsibilities as specified in sub-clauses (d), (g), (i) and (1).

\section{B. RESPONSIBILITIES Of DEALER}

It shall be the responsibility of a dealer to -

(a) Ensure that the used batteries are collected back as per the Schedule against new batteries sold.

(b) Give appropriate discount for every used battery returned by the consumer.

(c) Ensure that used batteries collected back are of similar type and specifications as that of the new batteries sold.

(d) File half-yearly returns of the sale of new batteries and buy-back of old batteries to the manufacturer in Form $\mathrm{V}$ by 31st May and 30th November of every year [1].

(e) Ensure safe transportation of collected batteries to the designated collection centres or to the registered recyclers.

(f) Ensure that no damage is caused to the environment during storage and transportation of used batteries [1].

(g) Ensure the following points

(1) Registration with State Pollution Control Board for five years and a provision of cancellation for failure in collection of the required number of used batteries as per the said rules, non-submission of timely half yearly returns to the State Pollution Control Boards, renewal of the registration shall be as per the compliance status, to submit details as Form IV, registration would be considered as deemed registered if not objected to within thirty days [2].

(2) An appeal shall lie against any order of suspension or cancellation or refusal of registration passed by the MemberSecretary of the State Pollution Control Board or any other officer designated by the State Pollution Control Board [2].

(3) The appeal shall be in writing and shall be accompanied with a copy of the order appealed against and shall be made within period of thirty days from the date of passing of the order [2].

\section{RESPONSIBILITIES of RECYCLER}

Each recycler shall -

(a) Apply for registration to the Ministry of Environment and Forests or an agency designated by it if not applied already, by submitting information in Form VI.

(b) Ensure strict compliance of the terms and conditions of registration, however, those already registered with the Ministry of Environment and Forests or an agency designated by it for reprocessing used batteries would be bound by the terms and conditions of such registration [1].

(c) Submit annual returns as per Form VII to the State Board [1]

(d) make available all records relating to receipt of used batteries, sources, quantities and metal yield to be submitted to the State Pollution Control Board for inspection [2].

(e) Mark 'Recycled' on lead recovered by reprocessing [1].

(f) Create public awareness through advertisements, publications, posters or others with regard to the following-

(1) Hazards of lead; and

(2) Obligation of consumers to return used batteries only to the registered dealers or deliver at the designated collection centres.

\section{RESPONSIBILITIES of CONSUMER or BULK CONSUMER}

(a) It shall be the responsibility of the consumer to ensure that used batteries are not disposed of in any manner other than depositing with the dealer, manufacturer, importer, assembler, registered recycler, re-conditioner or at the designated collection centres [1].

(b) It shall be the responsibility of the bulk consumer to -

(1) Ensure that used batteries are not disposed of in any manner other than by depositing with the dealer/manufacturer/registered recycler/importer/ re-conditioner or at the designated collection centers[1].

(2) File half-yearly return in Form VIII to the State Board [1] .

(c) Bulk consumers or their user units may auction used batteries to registered recyclers only.

\section{E. RESPONSIBILITIES of AUCTIONEER}

The auctioneer shall -

(a) Ensure that used batteries are auctioned to the registered recyclers only [1]

(b) File half-yearly returns of their auctions to the State Boards in Form-IX .

(c) Maintain a record of such auctions and make these records available to the State Board for inspection [1]. 
International Advanced Research Journal in Science, Engineering and Technology

Vol. 8, Issue 12, December 2021

DOI: 10.17148/IARJSET.2021.81239

V. CATEGORIES of BATTERIES

Different categories of batteries are as follows[ 7 ].

\section{A. ALKALINE BATTERIES}

Alkaline batteries are primary or non-rechargeable batteries. They typically consist of common metals such as steel, zinc, and manganese with a small amount of alkaline electrolyte.

\section{B. LEAD ACID BATTERIES}

Lead acid batteries are found in Uninterruptible Power Supply (UPS) units and vehicles. These batteries have a lead anode, a lead dioxide cathode and an aqueous solution of sulfuric acid.

C. NON-ALKALINE BATTERIES

This category of batteries consists of lithium-ion, nickel metal hydride, and nickel-cadmium batteries. Many of these battery types are marked with the word Rechargeable. The designation is based on the type of chemistry present in the battery. For example, lithium-ion batteries contain lithium, manganese dioxide, and an organic solvent; nickel metal hydride batteries contain nickel and a rare earth alloy to absorb hydrogen; and nickel-cadmium batteries contain nickel and cadmium metal as well as an alkaline solution.

\section{TREATMENT and DISPOSAL METHODS of BATTERIES WASTE}

Methods for the treatment and disposal of batteries waste are as follows.

\section{A. INCINERATION and LAND FILL}

Some batteries will be burned after they are discarded, but this will produce a lot of dust or tiny particles to pollute the atmosphere. Some batteries are buried in the soil together with municipal solid waste, but this requires high impervious measures, otherwise, it is very easy to cause serious pollution to the soil.

\section{B. CURING TREATMENT METHOD}

The solidification disposal method refers to the mixing of waste primary batteries with concrete ingredients in a certain proportion after crushing, and then the mixed concrete is used for paving roads or mixing with other building materials. This method has three advantages, one is to save the raw materials of concrete, the other is to improve the quality of concrete by using waste batteries, and the third is to reduce the pollution of waste batteries to the environment due to the characteristics of concrete. Although this method can deal with a large number of waste batteries in a short time, it does not solve the fundamental problem $[8,9]$.

\section{WET RECOVERY TECHNOLOGY}

Wet recovery technology is mainly to break the batteries after full discharge, then leach them with acid to produce soluble salt solution, and then electrolytically separate and purify the recovered metal. It is a commonly used waste battery treatment technology, such as chemical precipitation, solvent extraction, direct leaching and roasting leaching . The latter is more suitable for evaporating low boiling point metals such as mercury and cadmium. Typical processes of wet leaching process include alkali leaching of spent batteries to alkali leaching residue, acid dissolution and extraction after purification; acid leaching of spent batteries to adjust the $\mathrm{pH}$ value of solution to separate aluminium and other metals, and then separation of cobalt, nickel and lithium by ion exchange resin; immersion of spent batteries in NMP, separation of aluminium, copper foil and active materials, and filtration of graphite and cathode materials by acid leaching after sieving. The filtrate is precipitated with alkali solution. Electrolysis is also often used in the final metal purification. Wet recovery is prone to secondary pollution [10,11].

\section{DRY RECOVERY TECHNOLOGY}

Dry recovery technology mainly uses physical methods to break the battery after full discharge, roast at high temperature, and get the final product through a series of oxidation-reduction reaction and decomposition reaction, such as pyrometallurgy, mechanical separation, vacuum metallurgy, mechanical grinding method . The mechanical grinding method is to mix the separated electrode materials with abrasives and then grind them mechanically so that the positive active material can be converted into metal salts [12].

\section{E. BIOLOGICAL METHOD}

Biological method or Biometallurgy can be divided into bioleaching, biooxidation, biosorption and bioaccumulation. At present, bioleaching is the main method[13]. Metal components are usually separated and extracted by bacterial oxidation or biological oxidation, or by bacterial metabolites, such as the treatment of spent nickel-hydrogen batteries with acidophiles and their metabolites [14]. Mishra et al. leached metals from spent lithium-ion batteries with Thiobacillus ferrooxidans. Thiobacillus ferrooxidans utilizes elemental sulfur and ferrous ions as energy sources to produce sulfuric acid and iron ions by a series of redox reactions. It is found that ferrous ions can promote the growth 


\section{International Advanced Research Journal in Science, Engineering and Technology}

\section{Vol. 8, Issue 12, December 2021}

\section{DOI: 10.17148/IARJSET.2021.81239}

and reproduction of Thiobacillus ferrooxidans, while iron ions can inhibit the activity of Thiobacillus ferrooxidans[15]. Xin et al. [16] and Wu et al. [17] inoculated and treated electrode materials and strains (thiobacillus ferrooxidans and thiobacillus thiooxidans) of dismantled waste batteries, cultured for a period of time, and treated $\mathrm{LiCoO}_{2}$ with sulfuric acid produced by bacterial metabolism to form an extract containing $\mathrm{Co}^{2+}$. Although the metal extraction from waste batteries by biological method is relatively less polluted and environmentally friendly, it has obvious disadvantages, such as long leaching time, low leaching rate and low efficiency[18]. Moreover, it can only deal with the solution with low metal concentration, and the excessive metal concentration will affect the survival of microorganism.

\section{CONCLUSION}

The hazardous nature of batteries waste is one of the rapidly growing environmental problems of the world. In this study, the focus was on the management of batteries waste disposal. We have discussed the functional elements involved in batteries waste management (i.e. procedure of registration, responsibilities, batteries waste categories, methods for treatment and disposal). Subsequently we explained the methods of wastes disposal through land filling, incineration, curing treatment method, wet recovery technology, dry recovery technology and biological method to reduce their impact on public health and the environment. The result of the study demonstrate the need for strict enforcement of legal provisions and a better environment system for the disposal of batteries waste. Provision of a batteries waste management planning and monitoring system is a prerequisite issue for effective reduction of batteries waste associated risks.

\section{REFERENCES}

[1]. Gazette of India. S.O. 432(E) dated 16 May 2001, The Batteries (Management and Handling) Rules, 2001, Ministry of Environment and Forests, Government of India, New Delhi, India. 2001,

[2]. Gazette of India. S.O. 1002 (E) dated 4 May 2010, Batteries (Management and Handling) Amendment Rules, 2010, Ministry of Environment and Forests, Government of India, New Delhi, India. 2010

[3]. Linden, D. and Reddy, T. B. (ed.), Handbook of batteries, 3rd edition, McGraw-Hill, New York, 2002.

[4]. Crowl D.A. and Louvar J.F., Chemical process safety, 2nd edition, Prentice Hall PTR, New Jersey, 2002.

[5]. Environmental guideline for waste batteries, Department of environment, Government of Nunavut, 2011

[6]. Treatment of batteries within the Basel convention, 2009.

[7]. Ashok, K. Babu, Jula,V., \& Mullai, N.K(2021). Impact of used battery disposal in the environment. Linguistic and Culture Review,5(S1), 1276-1286.

[8]. C. Y. Lu, Talking about the Recovery and Utilization of Chemical Waste Batteries, The Guide of Science \& Education. 2x (2016) 147-148.

[9]. S. Y. Liu, Z. P. Wang, X. Y. Wang, L. Y. Chen, L. Luo, S. Zhang, Development and Recycling of Zinc Manganese Battery Industry, China's Manganese Industry. 34 (2016) 140-142.

[10]. Y. S. Liang, Talking about the Treatment and Comprehensive Utilization of Waste Batteries, Resources Economization \& Environmental Protection. 17 (2015) 11.

[11]. F. Pei, L. L. Lu, Y. Wu, W. H. Zhang, J. Yu, Study of recycling technology of used LiFePO4 batteries, Journal of Nanchang University(Natural Science). 37 (2013) 159-162, 167.

[12]. L. Li, E. S. Fan, J. R. Liu, F. Wu, Recycling Technology and Research Progress of Lithium Ion Batteries, Advanced Materials Industry. 9 (2016) 30-35.

[13]. J. H. Li, S. Zheng, D. L. Xiong, Y. Li, C. L. Tang, J. X. Yang, Methods for valuable resource recovery from cathode materials of spent lithium ion battery, Jiangxi Nonferrous Metals. 4 (2013) 29-35.

[14]. D. T. Zhang, Analysis on Recycling and Reuse of Waste Ni-MH Batteries, Science and Technology Innovation Herald. 10 (2015) 92.

[15]. D. Mishra, D. J. Kim, D. E. Ralph, J. G. Ahn, Y. H. Rhee, Bioleaching of metals from spent lithium ion secondary batteries using Acidithiobacillus ferrooxidans, Waste Management. 28 (2008) 333-338.

[16]. B. P. Xin, D. Zhang, X. Zhang, Y. Xia, F. Wu, S. Chen, L. Li, Bioleaching mechanism of Co and Li from spent lithium-ion battery by the mixed culture of acidophilic sulfur-oxidizing and ironoxidizing bacteria. Bioresource Technology. 100 (2009) 6163-6169.

[17]. F. Wu, B. P. Xin, Q. R. Zhu, Y. Sun, L. Li, A Method of Directly Digesting Metal Ions from Waste Batteries by Bioleaching Technology, P. China: CN123190, 1999

[18]. Y. Sun, F. Wu, B. P. Xin, L. Li, Effect of temperature on bioleaching of heavy metals from spent MH/Ni batteries, Environmental Pollution And Control. 5 (2013) 1-3, 9. 